\title{
Climate Change and Sea Level Rise
}

\author{
Nature of the State and of State Extinction
}

\author{
Seokwoo Lee and Lowell Bautista
}

\section{Introduction}

The birth and death of States present parallel inquiries in international law: each event requires an analysis of the characteristics of statehood, and each raises important questions of rights and obligations. ${ }^{1}$ A State is never static, and one can examine at different times its birth, its death and/or its rebirth, the nature of the State and the consequences that flow from such transformative events. ${ }^{2}$ Such an inquiry gives rise to practical questions: Is a State that is extinguished but reborn the same State that existed at the time of its extinction, even if it emerges years or decades later? And if it is not the same State, what is it, and what are its rights and obligations? The global impacts of climate change and rising sea levels pose serious threats to low-lying island States which may become uninhabitable due to the displacement of entire populations and potential complete disappearance of habitable territory under

1 The Montevideo Convention provides the most frequently cited definition of a State. Article 1 lists four basic elements required for statehood: (1) a permanent population; (2) a defined territory; (3) government; and (4) capacity to enter into relations with other States. Montevideo Convention on Rights and Duties of States, adopted 26 December 1933, in force 26 December 1934, 165 LNTS 19. J Crawford, The Creation of States in International Law (Oxford University Press, 2011) 4546; I Brownlie, Principles of Public International Law (Oxford University Press, 2008) 70-72; S Hall, Principles of International Law (Lexis Nexis Butterworths, 2014) 209-214; G Triggs, International Law: Contemporary Principles and Practices (Lexis Nexis Butterworths, 2011) 207-211; A Cassese, International Law (Oxford University Press, 2001) 46-56. There have been, in recent years, scholarly works which have criticized the definition of the State, including its failure to account for modern-day developments such as climate change, postcolonialism, and concerns regarding self-determination. See, for example, T Grant, 'Defining Statehood: The Montevideo Convention and Its Discontents' (1999) 37 Colombia Journal of Transnational Law 403-457, 435, 437, 449 .

2 As Shaw observes, '[s]ince terrae nullius are no longer apparent, the creation of new states in the future, once the decolonization process is at an end, can only be accomplished as a result of the diminution of disappearance of existing states, and the need for careful regulation thus arises'. See M Shaw, International Law (Cambridge University Press, 2008) 198. 
water. The current international legal regime does not adequately address the status of climate displaced populations and the capacity of these States to maintain their statehood. The traditional notion of State territory presumes the existence of a polity that has frontiers separating it from other States, and from international areas, such as the high seas and the Area. However, when the polity is rendered vulnerable to extinction through sea level rise, the concept of the frontier is challenged. The frontier may either need to be resituated, or abandoned as a physical construct altogether as the division between polities or between polities and international spaces are lost.

These are fundamental questions of international law. The international community's resolution of these issues may significantly impact the affected State, both in its foreign and domestic relations, especially given the potential confusion facing a State during those times of crisis. The State as a legal entity holds a privileged status in international law. ${ }^{3}$ The primacy of the State as a subject of international law implies that the loss of statehood carries with it the loss of this preferential status and the concomitant degradation of its international legal personality. It also entails significant loss of rights in international law. ${ }^{4}$ Accordingly, the birth and death of States is far from an academic inquiry.

Rising ocean levels brought about by climate change have created a flood of unprecedented legal questions for small island nations and their neighbours. ${ }^{5}$ The current inadequacy of international law to effectively protect the human rights of displaced citizens presents two interlocking issues. The first

3 The State in international law is given exclusive rights which are not given to other entities. For example, only States have the capacity to create treaties and customary international law. 1969 Vienna Convention on the Law of Treaties, 1155 UnTs 331, Art 1. Only States have the right to invoke the jurisdiction of the International Court of Justice. Statute of the International Court of Justice, 26 June 1945, 59 Stat 1031, Art 34(1). Only a State, a coastal State in this respect, is entitled to a territorial sea, an exclusive economic zone or a continental shelf, for example. 1982 United Nations Convention on the Law of the Sea (LOSC), 1833 UNTS 3, Arts 3, 56, 77 .

4 AG Jain, 'The 21st Century Atlantis: The International Law of Statehood and Climate ChangeInduced Loss of Territory' (2014) 5o Stanford Journal of International Law 1-52, 6-7.

5 J Kittel, 'The Global Disappearing Act: How Island States Can Maintain Statehood in the Face of Disappearing Territory' (2014) 2014 Michigan State Law Review 1207-125o; J Campbell, 'Climate-Induced Community Relocation in the Pacific: The Meaning and Importance of Land' in J McAdam (ed), Climate Change and Displacement: Multidisciplinary Perspectives (Hart Publishing, 2010) 57, 6o; MA Burkett, 'The Nation Ex-Situ' in MB Gerrard and GE Wannier (eds), Threatened Island Nations: Legal Implications of Rising Seas and a Changing Climate (Cambridge University Press, 2013) 89, 116-117; L Bautista, 'Legal and Policy Responses to Climate Change in the Philippines' in RS Abate (ed), Ocean and Coastal Law in the Climate Change Context: U.S. and International Perspectives (Oxford University Press, 2014) 647-664. 
one concerns the international legal status of forcibly relocated persons due to climatic change. Will they remain the citizens of the State whose territory has been rendered uninhabitable because of sea-level rise or will they be considered stateless? The second issue is the obligation of the international community to protect the human rights of displaced citizens in light of the protections accorded to stateless persons and refugees. ${ }^{6}$ Do the governments of such peoples survive, and if so, do they retain their full seats at the United Nations, even though they have no habitable land to control? And do they still control the fisheries and mineral rights to the surrounding seas that comprised the State's maritime zones, or do these waters become international waters? The questions are serious practical ones, and at the same time intellectually interesting. Practical solutions present a need to reconceptualize our understanding of statehood, particularly since territory, statehood and the rights of peoples are inextricably linked in international law.

This chapter will address the issue of the legal status of a single State at two points along its temporal continuum: the point at extinction and the point at reemergence. Then, it deals with a brief exposition of the nature of the State and the nature of State extinction. It also analyses the concomitant issue of State reemergence, with an emphasis on the theory of State succession as it relates to the issue of territory. ${ }^{7}$ This chapter reviews and challenges the traditional constitutive elements in the definition of a State under the Montevideo Convention of 1933 (permanent population, clearly defined territory, effective government, and capacity to engage in international relations), which are no longer adequate in the context of challenges posed by climate change. Specifically, the argument is made that territory may not be necessary to statehood once statehood has been firmly established and capacity is a consequence of statehood, not a criterion for its formation.

6 See M Burkett, "The Nation Ex-Situ: On Climate Change, Deterritorialized Nationhood and the Post-Climate Era' (2011) 2 Climate Law 345-374, 353; S McCullough, 'In a Rising Sea of Uncertainty: A Call for a New International Convention to Safeguard the Human Rights of Citizens of Deterritorialized Asia-Pacific Small Island-States' (2015) 26 Colorado Natural Resources, Energy \& Environmental Law Review 109-138; T Skillington, Climate Justice and Human Rights (Palgrave Macmillan, 2017); JG Stoutenburg, Disappearing Island States (Brill, 2015); Gerrard and Wannier (eds), ibid; J McAdam, Climate Change, Forced Migration, and International Law (Oxford University Press, 2012) 39-48.

7 See generally, C Blanchard, 'Evolution or Revolution: Evaluating the Territorial State-Based Regime of International Law in the Context of the Physical Disappearance of Territory due to Climate Change and Sea-Level Rise' (2013) 53 Canadian Yearbook of International Law 66118; R Rayfuse, 'Sea Level Rise and Maritime Zones: Preserving the Maritime Entitlements of "Disappearing" States' in Gerrard and Wannier (eds), above (n 5), 167-191. 
It can be concluded that if a State reemerges as a matter of fact after extinction having less territory than it had as its earlier incarnation, it may assert a claim to the territory of its erstwhile borders (and maritime entitlements). ${ }^{8}$ Competing claims to that State's territory, however, must be weighed, and treaty boundaries effected during the State's period of dormancy will presumptively bind that State, notwithstanding it not having been party to the treaty in question. ${ }^{9}$ There are possible scenarios for submerged island States. They could continue to be recognized as sovereign States, although their population and government are relocated. Alternatively, they could lose their 'statehood' and voting rights in international organizations, while the citizens retain passports and other privileges of sovereign immunity. Some countries may choose to no longer recognize these States, leading to international tensions and maritime disputes.

The territory of a State defines the limits of its sovereignty. ${ }^{10}$ Whilst territory as a prerequisite of Statehood is almost universally accepted, there is no rule requiring a minimum size or that the same be contiguous. ${ }^{11}$ The territory of a State may be small, fragmented, surrounded by huge expanses of water as in the case of mid-ocean archipelagos or even enclaved within the territories of other States. It is not the size of the land area but the effective exercise of

8 For academic literature on State succession, see Crawford, above (n 1), 667-672; M Craven, 'The Problem of State Succession and the Identity of States under International Law' (1998) 9 European Journal of International Law 142-162; O Schachter, 'State Succession: The Once and Future Law' (1993) 33 Virginia Journal of International Law 253-26o.

9 Vienna Convention on Succession of States in respect of Treaties, adopted 23 August 1978, in force 6 November 1996, 1946 UnTs 3. Article 11 of the Convention provides: 'A succession of States does not as such affect: (a) a boundary established by a treaty; or (b) obligations and rights established by a treaty and relating to the regime of a boundary'. See also, Articles 12, 13 and 15 .

10 In the North Atlantic Fisheries case, the Permanent Court of International Justice (PCIJ) stated: 'one of the essential elements of sovereignty is that it is to be exercised within territorial limits, and that, failing proof to the contrary, the territory is co-terminous with the Sovereignty'. North Atlantic Fisheries Arbitration, Award, (1910) 11 RIAA 167, 180. The principle of territorial integrity as enshrined in Article 2(4) of the United Nations Charter, which prohibits 'the threat or use of force against the territorial integrity and political independence of any state', is a recognized peremptory norm of international law. A Khan, 'The Extinction of Nation-States' (1992) 7 American University Journal of International Law and Policy 197-234, 198.

11 Crawford, above (n 1$), 46-47$. 
legislative and administrative functions that manifest territorial sovereignty, and determines statehood. A State continues to exist despite subsisting boundary or territorial disputes. The lack of definite or permanent borders has not been a basis for the denial of statehood. With respect to the question of the continued existence of a State if it loses territory due to climate change, the central issue that would arise is whether the complete and permanent loss of territory automatically results in the loss of statehood. ${ }^{2}$ This naturally would require an inquiry as to the relationship between territory and statehood. ${ }^{13}$ There exists an absolute nexus that exists between territory and sovereignty, even if the precise limits of that territory are uncertain. ${ }^{14} \mathrm{~A}$ State exercises control and jurisdiction over an objective geographical location or some area of territory that is land. However, the question remains how and when did territory become such an essential ingredient to the creation of States? ${ }^{15}$ What does territory give to a State that is critical for consideration as a full legal person within the international system? Given the substantial changes to the global community since the end of World War II, has the substantive element of territoriality been altered in any way? A full reflection upon these questions is beyond the scope of this short chapter, but an attempt will be made to contextualize and frame some of the critical issues that relate to the problem of a loss of territory due to climate change and statehood.

\subsection{The Historical Requirements of Statehood}

The importance of territory to an understanding of the nature of a State can be appreciated through the history of international law and how modern international law has come to its present-day conceptualization of the State. ${ }^{16}$ It is

12 MA Orellana, 'Climate Change and the International Law of the Sea: Mapping the Legal Issues' in Abate (ed), above (n 5), 253-271, 255-257.

13 Crawford, above (n 1), 46-52.

14 Cassese, above (n 1), 56. In the celebrated 1928 Island of Palmas case, Judge Max Huber stated that 'sovereignty in relation to a portion of the surface of the globe is the legal condition necessary for the inclusion of such portion in the territory of any particular State'. Island of Palmas (Netherlands $v$ United States), Award, (1928) 2 RIAA 829 at 838.

15 The earliest theory of international law espoused by Hugo Grotius is underpinned by the concept of territorial sovereignty. H Grotius, De Juri Belli Pacis Libri (The Law of War and Peace) Prolegomena $\S \S 14-15$ (F Kelsey trans. 1925) (original 1625); A Khan, 'The Extinction of Nation-States' (1992) 7 American University Journal of International Law and Policy 197, 202-203.

16 See generally, B Fassbender and A Peters, The Oxford Handbook of the History of International Law (Oxford University Press, 2012); O Yasuaki, 'When Was the Law of International Society Born: An Inquiry of the History of International Law from an Intercivilizational Perspective' (2000) 2 Journal of the History of International Law 1-66; 
often said that the roots of the modern international legal system emanated from the Peace of Westphalia (1648) ${ }^{17}$ According to this narrative, the Peace of Westphalia helped to usher in a new system of international relations in Europe which was to establish sovereign States that had exclusive authority over defined territories and was composed of people who had a common identity and culture. ${ }^{18}$

Political and legal authority in pre-seventeenth century Europe resided in two supranational institutions: the Papacy and the Holy Roman Empire which both claimed universality and unity in ecclesiastical and political rule. ${ }^{19}$ Christianity being the faith of Europe, the $\operatorname{church}^{20}$ created and applied canon law, which was 'supranational and even universal, exacting obedience all over the Christian world'. ${ }^{21}$

The Church asserted authority over the Empire as well. ${ }^{22}$ The 'Papal Revolution' of 1075 saw the assertion of power over secular matters including the authority 'to depose emperors and kings'. ${ }^{23}$ The Church held supreme and universal authority over the Empire through a feudal pyramid wherein the emperor gave gifts of land and granted royal titles of 'king' and 'prince' to lesser authorities who all owed fealty to him in exchange for soldiers when

A Orakhelashvili, Research Handbook on the Theory and History of International Law (Edward Elgar, 2011).

17 AS Hershey, 'History of International Law Since the Peace of Westphalia' (1912) 6 American Journal of International Law 30, 33, 38; MJ Kelly, 'Pulling at the Threads of Westphalia: Involuntary Sovereignty Waiver-Revolutionary International Legal Theory or Return to Rule by the Great Powers' (2005) 10(2) UCLA Journal of International Law \& Foreign Affairs 361-381, 364, 366, 372.

18 PH Wilson, The Thirty Years War: Europe's Tragedy (Harvard University Press, 2009) 754.

19 HJ Berman, Law and Revolution: The Formation of the Western Legal Tradition (Harvard University Press, 1983). Berman goes so far to argue that the first 'modern Western state ... was the church itself'. Referencing Maitland, Berman explains: '[I]t is impossible to frame any acceptable definition of the state which would not include the medieval church. By that [Maitland] meant the church after Pope Gregory VII, since before his reign the church had been merged with the secular society and had lacked the basic concepts of sovereignty and of independent lawmaking power which are fundamental to modern statehood. After Gregory vir, however, the church took on most of the distinctive characteristics of the modern state. It claimed to be an independent, hierarchical, public authority'. Ibid 113. See also, L Gross, 'The Peace of Westphalia, 1648-1948' (1948) 42 American Journal of International Law (1948) 20-41, 28.

$20 \quad$ NF Cantor, The Civilization of the Middle Ages (Harper Collins, 1994) 487.

21 A Nussbaum, A Concise History of the Law of Nations (Macmillan, 1954) 17.

22 BSA Korff, 'Introduction to the History of International Law' (1924) 18 American Journal of International Law 246-259, 255 .

Berman 1983, above (n 19), 87 . 
called upon and some amount of local control subject to overarching imperial law. While the political and legal authority of the Empire waxed and waned in the period before the Peace of Westphalia, imperial power and law was able to reach down to various local legal systems found in duchies and principalities as well as cities. ${ }^{24}$ Given this relative decentralization of authority under a supranational rule of 'one grand monarchy; consequently there could not be 'international' relations among its members (princes or free cities).'. ${ }^{25}$ Thus, because of the position and presence of the Papacy and the Holy Roman Empire, the 'medieval climate of the Western world was not favourable to the development of international law'. 26

Given this particular distribution of power, the notion of legal authority over a defined geographical space did not figure into the writings of the leading commentators of the time. For example, De Vitoria (1492-1546) described the State as a 'perfect community ... one that is complete in itself, that is, not a part of another community, but has its own laws and its own council and its own magistrates'.27 Grotius (1583-1645) described the State as 'a complete association of free men, joined together for the enjoyment of rights and for their common interests.' ${ }^{28}$ Pufendorf $\left({ }^{16} 3^{2-1694)}\right.$ understood 'the State to be 'a compound moral person, whose will, intertwined and united by the parts of a number of men, is considered the will of all, so that it is able to make use of the strength and faculties of the individual members for the common peace and security'.29 De Vattel (1714-1767) argued that the States were 'political bodies, societies of men who have united together and combined their forces, in order to procure their mutual welfare and security'. ${ }^{30}$ While it may have been assumed, a defined territorial space was not explicitly required in the epistemic conception of statehood in the Middle Ages. ${ }^{31}$

24 H Berman, Law and Revolution II: The Impact of the Protestant Reformations on the Western Legal Tradition (Harvard University Press, 2003) 33.

25 Nussbaum, above (n 21), 21.

26 Ibid 17.

27 JS Brown, The Catholic Conception of International Law (Lawbook Exchange, 2014) 35. Brown believed that Vitoria's understanding of a 'State' was the modern State of the twentieth century.

28 Crawford, above (n 1) 6. Crawford understands Grotius' definition as being 'philosophical rather than legal'.

29 Ibid.

$30 \quad$ ED Vattel, Le Droit Des Gens, Preliminaries (1758) para 1.

31 Crawford's understanding of these definitions of a State was that they were 'based on scholastic argument'. Crawford, above (n 1$) 6$. 
However, the political and legal landscape in Europe would undergo revolutionary changes that would change the dynamics of authority that would see the creation of an order that was less and less supranational in character, but one that was becoming more and more international. This transformation was brought along by an obscure German monk who posted to the door of the Wittenburg Castle church questions and comments regarding the Church and its practices. This act by Martin Luther in 1517 'began as a loud call for freedom - freedom of the Church from the tyranny of the Pope, freedom of the laity from the hegemony of the clergy, freedom of conscience from the strictures of canon law'.32 The Protestant Reformation beginning in Germany spread elsewhere in Europe. This challenge to the existing Church order and to the Papacy for reformation led to a tumultuous period in European history during which time the freedom to worship became a focal point in the struggles between the territorial princes and the Papacy with the support of the Holy Roman Empire. ${ }^{33}$

These struggles eventually led to open warfare in Germany resulting in conflict between the princes who were aligned with Luther and his teachings, the Schmalkaldic League, against those princes who remained within the Roman Catholic fold and against the Holy Roman Empire itself under Charles v. The resolution of this conflict was the Peace of Augsburg (1555) which allowed each prince to decide what religion would be practiced in their territory. ${ }^{34}$ The feudal prince who was subject to both the Pope and the Emperor now had a measure of authority which he previously did not possess for the territory he was responsible for. Beginning in Germany, the Reformation helped to bring about

32 J Witte, Jr, Law and Protestantism: The Legal Teachings of the Lutheran Reformation (Cambridge University Press, 2002) 1.

33 'It was the alliance of Lutherans with territorial princes, and of those princes with one another, which - more than any other single factor-secured the victory of Lutheranism in the territories in inhabited by a majority of the German people'. Berman 1983, above (n 19), 49. Berman notes that not all the princes who eventually supported Luther were committed to Luther's theological positions, but were 'only defending their own powers and rights against the emperor and pope. Indeed the grievances of the princes coincided in many respects with Luther's grievances'. Ibid. See also, H Steiger, 'From the International Law of Christianity to the International Law of the World Citizen-Reflections on the Formation of the Epochs of the History of International Law' (2001) 3 Journal of the History of International Law 180-193.

34 Berman 2003, above (n 24), 5o. According to Berman, 'it is undeniable that hegemony of the Roman Catholic Church over the German principalities was finally broken by the Peace of Augsburg, which finally established the new principle that within the community of states that made up the German nation, the religion of each territorial rulerRoman Catholicism or Lutheranism — was to be the sole religion of his territory'. Ibid 5 o. 
a substantial reconfiguration of political and legal authority on the European continent and set in motion the conceptualization of territorial exclusivity in relation to the authority of the Papacy and the Empire.

About 100 years later, Europe was embroiled in another conflict lasting thirty years ending with the Peace of Westphalia that furthered the notion of territorial exclusiveness. 'The effect of the Peace of Westphalia was to consolidate the existing States and principalities (including those whose existence or autonomy it recognized or established) at the expense of the Empire, and ultimately at the expense of the notion of civitas gentium maxima - the universal community of mankind transcending the authority of States.35 It continued the earlier movement towards stronger control of the territorial princes over the subjects in their territories. ${ }^{36}$ While the settlement at Westphalia did not have the immediate effect of creating a new international order within Europe, it did demonstrate that Europe was shifting to a secular order that was based on sovereign equality. ${ }^{37}$

Accordingly, the prevailing view is that the modern (Westphalian) State arose from the settlement created in the political and legal arrangement that was used to resolve the Thirty Years War. ${ }^{38}$ It spurred on the conditions for a new world order that would eventually be based on the principle of territorial sovereignty. ${ }^{39}$ As Shaw notes:

This order involved the recognition of all independent states as having equal rights of sovereign jurisdiction over a determined territory. This sovereign equality of states was founded upon the exclusivity of action of each state within its defined territory and the right of all states to participate within the sphere of international relations. ${ }^{40}$

35 Crawford, above (n 1), 10.

36 According to Wilson, '[t]he war's main impact was not to loosen the bonds between Empire and its component territories, but to strengthen the authority of the latter over their subjects'. Wilson, above (n 18), 777.

37 Ibid.

38 'It is only around the peace of Westphalia (1648), which put an end to the sanguinary Thirty Years War, that the modern state emerged as an international subject and the international society took its current shape'. A Cassese, 'States: Rise and Decline of the Primary Subjects of the International Community' in Fassbender and Peters (eds), above (n 16), 5 o.

39 'The [Peace of Westphalia] clearly associated territorial sovereignty with electors, princes and magistrates of imperial cities, eliminating all chance of intermediary bodies within the territories claiming such rights themselves. Wilson, above (n 18), 777 .

40 MN Shaw, 'Territory in International Law' (1982) 13 Netherlands Yearbook of International Law 62. "The classic "Westphalian state" rests on indivisible sovereignty that both excludes external agencies and does not share the exercise of internal governance with 
Therefore, whereas the pre-Westphalian order conceived of jurisdiction over persons and subjects allowing for multiple authorities (e.g., the local prince or elector, the Church and the Empire) to exercise political and legal power within the same geographical space, the Peace of Westphalia signalled a shift towards jurisdictional exclusivity of one sovereign over a defined territory. ${ }^{41}$

The strict requirement of a defined territory as an essential element of statehood was not immediately established after the Thirty Years War as the transition to a truly 'international' system for relations between independent territorial States involved a lengthy process. ${ }^{42}$ Indeed, the aftermath of the War did not see the formal demise of the Holy Roman Empire until August 1806 nor did the Papacy lose authority over those persons and places that pledged their allegiance to the Roman Catholic faith ${ }^{43}$ Given the continuing, albeit weakened, authority of the Empire, the presence of the Roman Catholic Church and territorial actors presented a practical problem as to how to recognize and engage these new territorial entities. It was at this time that Gottfreid Wilhelm Leibniz (1646-1716), the German philosopher who is commonly known for his work in mathematics, developed a pragmatic yet normative understanding of how authorities old and new could interact with each other. Coining the term 'international legal personality,' he proposed engagement of the various postWestphalian rulers on the basis of relative sovereignty whereby even if the ruler did not have jurisdiction on some matters within his domain, he could possess international legal personality if he had the right of territorial hegemony and a large territory. ${ }^{44}$

other domestic bodies. In addition, it possesses well-demarcated, non-porous borders, and a common identity and culture among its inhabitants'. Wilson, above (n 18), 754. The Montevideo Convention, however, states that the 'political existence of the state is independent of recognition by the other states', which may be explicit or tacit. Montevideo Convention, above (n 1), Arts 3, 7. See also, A Murphy and V Stancescu, 'State Formation and Recognition in International Law' (2017) 7 Juridical Tribune 6.

41 'The delegitimization of all other forms of the exercise of supreme political authority in and over territory has indeed been a continuous feature of the evolution of the very distinct "Westphalian model" of the symbiosis between a people and its territory'. D-E Khan, 'Territory and Boundaries' in Fassbender and Peters (eds), above (n 16), 234-235. Wilson, above (n 18), 754 .

43 According to Berman, the Peace of Westphalia reaffirmed the 'the principle of royal supremacy over church and state'. Berman 2003, above (n 24), 62. Wilson notes that ' $[t]$ erritorial rulers remained bound by imperial law that took precedence over their own legislation'. All alliances made by territorial rulers were subject to the principle that they were not prejudicial to the emperor or Empire. Wilson, above (n 18), 777 .

44 J Nijman, Leibniz's Theory of Relative Sovereignty and International Legal Personality:Justice and Stability or the Last Great Defence of the Holy Roman Empire, IILJ Working Paper No 2004/2 (Institute for International Law and Justice, New York University School of Law, 
From Leibniz's perspective, territory was an essential element to establish some measure of international legal personality for entities today that would not be considered sovereign States. The notion of international legal personality itself has undergone changes as it became identified with statehood in the late nineteenth and early twentieth centuries. ${ }^{45}$ The association of a particular territory as a requirement for statehood would also come around the same time. ${ }^{46}$ 'Unanimity prevails that territoriality is a defining attribute of the Westphalian State and it is probably even correct to assume that a 'territory owner ethos' constitutes the most distinctive feature of traditional international law' ${ }^{47}$

Thus, it is clear that the modern characteristics of statehood are the product of a long and chequered history, largely post-Reformation in Western Europe. This reflects the shift in international law to a more positive basis, drawing on wider scientific notions which are more strongly rooted in empirical fact, rather than divine law. This development or evolution further consolidated the factual basis of certain legal states of affair. The importance of a community, disembodied from a defined territory, has lost resonance in modern-day conceptualization of statehood. However, the embryonic formulation of States was essentially non-territorial. The idea that the political organization of a State has to be territorial is not an axiom, but rather a political contingency or a theoretical construct.

\section{$2.2 \quad$ The Nature of the State}

According to Kelsen, 'Traditional [international law] doctrine distinguishes three 'elements' of the State: its territory, its people, and its power exercised by an independent and effective government. It is assumed to be of the essence of a State that it occupies a certain limited territory'48 The requirement of territory has been consistent among various commentators since the nineteenth

2004) 37; see also, JE Nijman, The Concept of International Legal Personality: An Inquiry into the History and Theory of International Law (TMC Asser Press, 2004).

45 Crawford, above (n 1), 29.

46 According to Daniel-Erasmus Khan, the view that statehood presupposes a territorial basis was only espoused in the late nineteenth century. The seminal 'three-element theory' (territory, population, ultimate ruling power) of Georg Jellink, which concedes the spatial element as conditio sine qua non for statehood reflecting similar thoughts of that period, is a departure from seventeenth- and eighteenth-century post-Westphalian works on the same topic. D Khan, 'Territory and Boundaries' in Fassbender and Peters (eds), above (n 16), 234 .

47 Ibid 233 .

48 H Kelsen, Principles of International Law (Lawbook Exchange, 1952) 207. 
century. ${ }^{49}$ The 1933 Montevideo Convention on Rights and Duties of States, which now reflects customary international law, provides a legal albeit less theoretical definition of statehood: a permanent population; a defined territory; a government; and the capacity to enter into international relations. ${ }^{50}$

It is clear that as far as understanding what a State is, contemporary rules of international law will not accept a territory-less entity that would otherwise meet the requirements of statehood as a State. ${ }^{51}$ The question of the formation of States is subject to whether recognition is constitutive for, or declaratory of, the creation of States in international law. A State's existence as an international legal person, in the traditional formulation of the declaratory theory of Vattel, Moore, Brierly, and Chen, is independent of its recognition by existing States. Recognition in this sense is merely a formal acknowledgment of an already existing fact with erga omnes effect vis-à-vis all existing and future States and other subjects of international law. ${ }^{52}$ On the other hand, from a constitutive perspective, unless recognition is accorded by other States, it will not acquire legal personality despite possessing all the formal attributes of statehood. ${ }^{53}$

These elements of statehood represent the objective requisites of statehood. Despite changes in the quality of these individual elements, the State persists. As Lauterpacht observed, '[a] State remains one and the same International Person in spite of changes in its headship, in its dynasty, in its form, in its rank and title, and in its territory'.54 No State lacking these elements can exist in perpetuity, but a State may temporarily lose one or more of these elements

49 'Territory and population are conditions necessary for the existence of a state'. GG Wilson, Handbook of International Law (West Publishing, 1910) 23; 'The concept of the State is rooted in the concept of control of territory. The purpose and role of every State is to control activities within its borders so far as possible, or more accurately to ensure that activities within its borders are not regulated by any other State'. V Lowe, International Law (Oxford University Press, 2007) 138; 'A state without territory is not possible, although the necessary territory may be very small'. R Jennings and A Watts (eds), Oppenheim's International Law (9th edn, Longman, 1992) 563; 'Evidently, States are territorial entities.... [T] he right to be a State is dependent at least in the first instance upon the exercise of full governmental powers with respect to some area of territory'. Crawford, above (n 1), 46 .

$5^{\circ} \quad$ Montevideo Convention, above (n 1$)$, Art 1.

$5^{1}$ Wong asserts that there are at least two entities that support the proposition that a State may come into existence without territory: the Sovereign Military Hospitaller Order of St John of Jerusalem, of Rhodes and of Malta ('Order') and the Holy See. D Wong, 'Sovereignty Sunk: The Position of Sinking States at International Law' (2013) 14 Melbourne Journal of International Law 346, 356-358.

52 D Raic, Statehood and the Law of Self-Determination (Kluwer, 2002) 32.

53 Crawford, above (n 1$)$, 19.

54 L Oppenheim, International Law: A Treatise, Vol 1 (Lawbook Exchange, 2005) 141. 
entirely and yet survive in limbo. The State may repeatedly suffer fluctuations in its population, territory, or government and yet return to equilibrium. This return, however, presumes non-destructive fluctuations in the system, for any destructive changes vitiate the system. An island State that sinks, for example, is clearly not a State. Nonetheless, the criterion of territory is relatively indeterminate in the modern conception of statehood for the purpose of international law. It is this ambiguity that allows scope for a broad interpretation of this element of statehood.

To discover if a certain entity is a State for international law purposes, it is not enough simply to ascertain empirically whether the State has an effective government that represents to the world a defined people in a delimited territory. That inquiry is both under-inclusive and over-inclusive. It is underinclusive because it fails to ask whether the international community has conferred legal status on a putative State. It is over-inclusive because it fails to account for bona fide States that have been deprived of one or more criteria of statehood. Thus, in examining the birth and death of a State, one's eyes must remain fixed on the State's legal personality and, hence, on international law.

International law, however, cannot fashion States from its own cloth; a State must possess the necessary characteristics of statehood. If international law cannot create the State, it cannot extinguish the State. Independent of and irrespective of recognition by other States, the status of statehood is generated, and the State as an entity with rights and obligations does not cease to exist. The dichotomist who seeks to label a State 'new' or 'old' succeeds, then, only in obfuscating the central issue: the State's extant legal personality. The recognition of statehood is premised on its de jure existence based upon the objective factual existence of the accepted criteria of statehood. However, a State that once enjoyed recognition continues to exist and persists as a legal entity with the rights and duties of a State. The total loss of all territory of a State when it is completely submerged and its entire population dispersed, challenges the factual persistence of a State but the State's abstract legal personality persists.

As Marek notes, 'international law alone ... provides the legal evaluation of the process, determines whether an entity is in fact a State, delimits its competence and decides when it ceases to exist'.55 Thus, Marek posits, this is never a theoretical inquiry into the 'internal identity and continuity' of States, for that problem is artificial. ${ }^{56}$ The legal personality of the State is not constructed upon a territorial basis which needs to remain static in perpetuity. The State

\footnotetext{
55 K Marek, Identity and Continuity of States in Public International Law (Librairie Droz, 1968) 2-3.

56 Ibid 3.
} 
as a subject of contemporary international law remains a holder of rights and duties notwithstanding fluctuations in the size and diminution of its territory.

\subsection{The Extinction of State}

In modern times, it is no longer an impossibility, albeit a rare event, to contemplate the extinction of the State through the total disappearance of a State's territory or people. ${ }^{57}$ Nonetheless, the complete inundation of a State's territory or total displacement of its citizens is not likely to happen suddenly. ${ }^{58}$ The extinction of States, according to Oppenheim, 'will hardly occur in fact' and will occur in instances of 'merger of one State into another, annexation after conquest in war, breaking up of a State into several States, and breaking up of State into parts which are annexed by surrounding States. ${ }^{59}$ In the post-World War II era, instances of State extinction have been very uncommon. Whilst numerous States have come into existence in this period, a very small number of States have disappeared completely in any sense. The predominant cases of voluntary extinction occur by merger, absorption, or dissolution, and cases of involuntary extinction through annexation and invasion. ${ }^{60}$ The extinction of States through changes in the political order, which is the dominant mode in the law of statehood, is different from the material extinction of States as a consequence of rising sea levels brought about by climate change.

The issue of extinction arises, then, only when legitimate doubts are raised as to a State's continued legal viability. Revolution or invasion (coupled with annexation or belligerent occupation) may leave a State a spectre of its former

57 Wong, above ( $\left.\mathrm{n}_{51}\right), 346,348$ (writing in 2013). In 1905, Oppenheim wrote: 'Theoretically such extinction of International Persons is possible through emigration or the perishing of the whole population of a State'. Oppenheim, above ( $(\mathrm{54}), 117-118$. Alfred Soons, writing in 1990, stated that the physical disappearance was 'far-fetched and purely hypothetical'. AHA Soons, 'The Effects of a Rising Sea Level on Maritime Limits and Boundaries' (1990) 37 Netherlands International Law Review 207-232, 229.

$5^{8}$ Jain, above (n 4), 1, 6. Despite strong evidence showing the connection between climate change and forced migration, there currently exists no legal recognition that establishes the connection between climate change and displaced persons, let alone the popularized sub-category of refugees labelled as 'climate change refugees'. According to Berchin et al., a 'climate change refugee' refers to 'any person who has been forced to leave their home, or their country, due to the effects of severe climate events, being forced to rebuild their lives in other places, despite the conditions to which they are subjected'. II Berchin, IB Valduga, J Garcia and JB Andrade Guerra, 'Climate Change and Forced Migrations: An Effort Towards Recognizing Climate Refugees' (2017) 84 Geoforum 147-150.

59 Oppenheim, above ( $\left.\mathrm{n}_{54}\right), 143$.

6o Crawford, above (n 1$), 702-717$. 
self. ${ }^{61}$ Nonetheless, the legal personality of the State is preserved. There exists a strong presumption that is in favour of continuity and which disapproves the extinction of an established State. ${ }^{62}$

Commentators typically simplify the problem of extinction of States. Kelsen finds the sole criterion of extinction in the absence of effectiveness of a State's legal order. The line of thought, however, has its limits. A State may survive temporary belligerent occupation during which time the rightful government is ousted. Further, a State may exist, in which its legal order falls under other State or States. Lauterpacht is similarly unhelpful, asserting that '[a] State ceases to be an International Person when it ceases to exist. ${ }^{63}$ This tautology suffices when there is no vestige of the former State's legal personality, e.g., an island nation sinks, a population emigrates or is displaced in toto, but it says nothing when the inquiry is precisely whether a legal personality exists, or when that legal personality died. Seeking enlightenment on this score from the traditional doctrines of extinction - dismemberment, merger, and debellatio proves equally unhelpful: these doctrines illuminate modes of extinction but provide no analytical framework for conceptualizing the problem.

Marek presents a compelling theory. International law recognizes the presumption of continuity of States, and so the issue of extinction arises only in extraordinary circumstances. Two international legal principles may collide when State extinction is questioned: ex injuria ius non oritur and ex factis ius oritur. Marek notes, 'the effectiveness of the illegal act must be final beyond doubt and every reasonable chance of restitutio ad integrum must be excluded' ${ }^{64}$ But, effectiveness, or ex factis ius oritur, does not always win the day. A State may exist in a zone of twilight, in which it objectively lacks the elements of statehood, and yet it clings to life. The new situation, born of the circumstances which brought about the loss of the characteristic of statehooda defined territory above water for instance - needs to be final, without the reasonable possibility of restoration. The extinction of a State through climate change is not, in a logical sense, voluntary in nature. In this sense, the historical presumption against involuntary extinction of States under the maxim of

61 Crawford (ibid 688-689) opines that belligerent occupation does not affect the continuity of the State, and the annexation of the territory of a States as result of illegal use of force (e.g., the annexation of Kuwait in 1990 to 1991) does not result in the extinction of the State.

62 Ibid 701; Marek, above (n 55), 548; O Schachter, 'State Succession: The Once and Future Law' (1993) 33 Virginia Journal of International Law 253-26o, 258-26o.

63 Oppenheim, above (n 54), 143, which will occur 'through emigration or the perishing of the whole population of State, or through permanent anarchy within a State'.

64 Marek, above (n 55), 329. 
ex injuria jus non oritur should not be operative. Nonetheless, the law cannot be separated from the practical consequences of facts as they exist, and must yield to the contrary principle ex factis jus oritur. The disappearance of States due to rising sea levels is not a simple question of the legal persistence of a State in the face of unlawful actions, but rather undeniable, indefinite conditions which are interwoven with the current conception of statehood.

Under such circumstances, third States can help resuscitate the States in peril; but simply pronouncing a dead State alive does not, in fact, breathe life into that moribund State. State practice reflects, and is constrained by, extant international law. Although climate change and sea level rise may place a State's life in limbo, 'international law cannot withstand a permanent divorce between validity and effectiveness under the threat of becoming a fiction to the point of disappearance, and that, consequently, such a permanent divorce must end by a new adaptation of fact to law or vice-versa.' ${ }^{65}$

In these cases, there is no legal remedy. This certainly remains true, though one hopes that the international organizational machinery can rectify the egregious situation caused by climate change and sea level rise. However, the final transformation of a temporary fact and situation into a permanent one will give rise to a new legality. In the absence of an effective international organization, international law will have to capitulate before the overwhelming normative pressure of facts. The continued existence of a State despite failing to meet the objective or factual characteristics of statehood persists with the continued recognition by the community of States and international bodies such as the UN. However, as the sea submerges all the land of a State, the criterion of territory is obliterated and a foundational attribute of the factual existence of a State is lost. As the bases of its original existence disappear, the State can no longer be reasonably considered to persist, and the factual disappearance of the State would likely be followed by its legal disappearance. That stage may be postponed, but it cannot be avoided. Climate change may render a State both factually and legally extinct. This tendency of, and necessity for, international law to capitulate before overwhelmingly strong facts is the only true and straightforward explanation of, and the only reason for, the new legality. Torn between validity and effectiveness, international law will finally have to choose effectiveness in order not to become illusory. The land will become uninhabitable long before it actually disappears due to climate change. Because of this, populations will be displaced and the statehood indicia of permanent population, effective government, and capacity to enter into

65 Ibid 577. 
relations with other States will be problematic some time before the lack of a physical territory.

Low-lying island States are facing a truly novel situation. ${ }^{66}$ There is no modern precedent for a country losing its territory through climate change rather than through annexation, conquest, or sale. Scholars are beginning to wrestle with the issue of what happens to a State that becomes uninhabitable and/or loses its territory because of changes caused by climate change, but comparatively little has been written that is directly on point. Much of the discussion of the legal ramifications of climate changes focuses on the status of displaced persons and addresses the issue in a human rights framework highlighting the need for additional legal protections because displaced persons that cross international borders will not meet the traditional definition of 'refugees'. ${ }^{67}$ The needs and rights of affected individuals must be central to all responses. International human rights law should afford protection to environmentally displaced persons. The principles of human dignity, non-discrimination and international cooperation must be paramount in any response to climate change and the disappearance of States, as well as the criteria of statehood.

Questions of statehood and statelessness are generally laden with controversy and emotion, yet with Pacific islands, for example, at risk of becoming gradually uninhabitable and entirely submerged under rising seas, along with losing their sovereignty and lucrative marine rights, there is an urgent need for legal solutions. Solutions are available, even if uncertainties surrounding precedents and current options mean they will depend as much on politics as they will on law.

What if climate change alters the map? According to customary international law as codified in the 1933 Montevideo Convention, a State must have a permanent population, a defined territory, a government, and the capacity to enter into relations with the other States to be considered sovereign. ${ }^{6}$ Nevertheless, even without climate change taken into account, not all recognized States today conform to all these requirements, and some academics have long argued that the definition is inadequate. ${ }^{69}$ For instance, whilst the

66 See, for example, DD Caron, 'When Law Makes Climate Change Worse: Rethinking the Law of Baselines in Light of a Rising Sea Level' (1990) 17 Ecology Law Quarterly 621-654, 634; DD Caron, 'Climate Change, Sea Level Rise and the Coming Uncertainty in Oceanic Boundaries: A Proposal to Avoid Conflict', in S Hong and JM Van Dyke (eds), Maritime Boundary Disputes, Settlement Processes and the Law of the Sea (Martinus Nijhoff Publishers, 2009) 1-17.

67 See McAdam 2010, above ( $\left.\mathrm{n}_{5}\right), 39-5$.

68 Montevideo Convention, above (n 1 ), Art 1.

69 The classical definition of the requirements of a State in Article 1 of the Montevideo Convention has been criticized for being 'unclear, imprecise or incomplete'. Wong, above 
existence of a permanent population is required, there is no specified minimum number of inhabitants needed, as Nauru and Tuvalu, demonstrate. ${ }^{70}$ Territory as a requirement does not need to be defined and settled, as demonstrated by States such as Albania prior to the First World War which was recognized by many countries despite its borders being in dispute, or Israel with its unsettled frontiers and hostilities with its Arab neighbours over its territory. ${ }^{71}$ Thus, there is scope for flexibility in the application of the requirements of statehood which may apply to States threatened by climate change.

With regard to climate change, there is no precedent for a State losing its territory for any reason other than war, annexation or the sale of land. One option for a State threatened with submersion to retain its sovereignty is to purchase new territory if it is available. For example, the Indonesian government has agreed to rent out one of its thousands of uninhabited islands to the Maldives. ${ }^{72}$ Another possibility could be the resettlement of the State's citizens into a receiving State, in which they would retain some autonomy. This option, however, is fraught with political difficulties, and so far, it is mostly unprecedented, as movements tend to be within one country rather than between countries. ${ }^{73}$ Another option is the construction, within the limitations of existing technology, of an artificial structure, or man-made island that is permanently above sea level. However, current international law, consistent with the United Nations Convention on the Law of the Sea regime, does not recognize artificial islands, installations and structures as possessing the status of islands or territory. ${ }^{74}$

Much of the focus so far is on the loss of the factual conditions for statehood. However, statehood, and specifically, independence is both legal and factual. The factual conditions are those four elements prescribed under the Montevideo Convention noted above. Legal independence is a status conferred by the international community through (individual and collective) acts

(n 51), 348. See also, M Craven, 'Statehood, Self-Determination, and Recognition' in MD Evans (ed), International Law (Oxford University Press, 2010) 220; Shaw, above (n 2), 199; TD Grant, 'Defining Statehood: The Montevideo Convention and Its Discontents' (1999) 37 Columbia Journal of Transnational Law 453, 454; J Crawford, Brownlie's Principles of Public International Law (8th edn., Oxford University Press, 2012) 128.

70 Populations of about 12,00o and 10, ooo respectively. Shaw, above (n 2), 199.

71 Ibid 199-200. See also, Wong, above (n 51), 356-358.

72 J McAdam, 'Disappearing States', Statelessness and the Boundaries of International Law' in McAdam 2010, above (n 5), 105-130, 122.

73 McAdam 2012, above (n 6), 143-147, who discusses the scenario of en masse relocation of a State's population in another country.

74 Wong, above (n 51$), 384$; LosC, above (n 3$)$, Art 6o(8). 
of recognition. Even if an uninhabitable island is no longer factually independent, it can still be recognized by other States as legally independent as long as it maintains a certain number of population or, in the case of complete submersion, if it maintains a functioning government, even one located in another State, that claims continued statehood. ${ }^{75}$ The Order of Malta and the Holy See are said to be analogous to this concept of the 'deterritorialized State'. Some scholars contend that functional sovereignty is recognized in entities such as the European Union and Taiwan, as well as in governments in exile. ${ }^{76}$ Only if the majority of the world's States decided not to recognize it any longer would the island no longer be legally independent, but that is an unlikely scenario. Morally, other countries would have an obligation to support the islands' continued existence. Politically, many would want to avoid setting dangerous new precedents.

Other options include a trusteeship run by the islanders with financing from other countries, a 'nation ex situ' that can hold a scattered Pacific island diaspora together and would align well with today's global, cross-border citizenships and rich online communities. But it also remains unclear how an island diaspora would work without the land and resources that form the basis of its cultural identity.

This one example highlights the difficulty surrounding possible solutions to safeguard the islanders' statehood if the worst-case scenario becomes a reality - a reality that is extraordinarily challenging for islanders to contemplate, not least because today's generation may be challenged by a statehood they struggled to achieve. But if discussing legal theories in advance of submersion prepares the world for such changes and smooth inevitable political difficulties, that statehood - while hardly ideal - will at least not be lost.

Much of the discussion concerning long-term options for small-island States facing imminent submersion, or risk of inhospitable territory, concerns internal and external relocation of climate displaced populations. ${ }^{77}$ Coastal States which possess low-lying territories, as well as small-island States are

75 Crawford, above (n 1$), 678$.

76 Wong, above (n 51$), 385$.

77 See, for example, McCullough, above (n 6); M Gagain, 'Climate Change, Sea Level Rise, and Artificial Islands: Saving the Maldives' Statehood and Maritime Claims through the Constitution of the Oceans' (2012) 23 Colorado Journal of International Environmental Law and Policy 77-120; PD Warren, 'Forced Migration after Paris COP21: Evaluating the “Climate Change Displacement Coordination Facility" ' (2016) 116 Columbia Law Review 2103-2145. 
confronted with the prospects of a diminution of maritime jurisdictional entitlements and the loss of associated marine resources, and the more grave consequence of the loss of statehood. ${ }^{78}$ However, in reality, small island States are likely to become uninhabitable long before the islands physically disappear by total inundation. ${ }^{79}$ Consequently, in this sense, it is the absence of a permanent population rather than a defined territory that augur adversely that an entity no longer manifests the full indicia of statehood as defined in contemporary international law. Nonetheless, to treat these elements as disparate would be inoperable as they are closely intertwined. ${ }^{80}$

\section{Concluding Remarks}

Climate change raises novel questions which ask the international community to revisit the foundational bases upon which States are constituted. Whilst framed in the abstract, this inquiry is certainly not purely academic in nature. It is obvious that international law does not directly address the question of State extinction confronting island States due to climate change. The imminence and inevitability of outright physical disappearance of all the land territory of a State due to rising sea levels presents a lacuna in the law. An inquiry into the legal rules in respect of the extinction of States contextualizes and recognizes the phenomenon of a rapidly changing physical world impacted by climatic changes whose consequences are not easily accommodated by existing theories of international law. The disappearance of States is fraught with practical and legal difficulties especially for small island States and low-lying coastal States as well as the entire community of nations. In the same manner as the physical boundaries of States recede, wane - and for some States, could gradually disappear - the extinction of States presents a compelling challenge to the very legal boundaries of State and statehood in international law. The complete submersion or total inundation of the entire territory of a low-lying

78 C Schofield, 'Departures from the Coast: Trends in the Application of Territorial Sea Baselines under the Law of the Sea Convention' (2012) 27 International Journal of Marine and Coastal Law 723-732, 725-726. It is a relief that Schofield notes that '[w]hile such concerns are not to be blithely dismissed, they do not appear to be likely in the short- to medium-term'.

79 See discussion the impact on statehood of the loss of territory for small-island States and low-lying coastal States in Kittel, above (n 5); L Yamamoto and M Esteban, 'Vanishing Island States and Sovereignty' (2010) 53 Ocean \& Coastal Management 1-9, 4.

8o CE Werrell and F Femia, 'Climate Change, the Erosion of State Sovereignty, and World Order' (2016) 22 Brown Journal of World Affairs 221-236. 
island State and its potential consequences, which may result in the loss or extinction of statehood - both factual and legal - should not be dissociated with the plight of its inhabitants, whose inherent rights and welfare need to be protected, upheld, and safeguarded. 